\title{
Congenital adrenal hyperplasia due to 3- beta-hydroxysteroid dehydrogenase deficiency
}

INSERM

\section{Source}

INSERM. (1999). Orphanet: an online rare disease and orphan drug data base. Congenital adrenal hyperplasia due to 3-beta-hydroxysteroid dehydrogenase deficiency.

ORPHA:90791

Cong enital adrenal hyperplasia due to 3-beta-hydroxysteroid dehydrogenase deficiency is a very rare form of congenital adrenal hyperplasia (CAH; see this term) encompassing salt-wasting and non-salt wasting forms with a wide variety of symptoms, including glucocorticoid deficiency and male undervirilization manifesting as a micropenis to severe perineoscrotal hypospadias. 